\title{
ПАРАМЕТРИ ПРЯМОГО ПОТОКУ СОНЯЧНОЇ ЕНЕРГІЇ ПРИ ЯСНОМУ НЕБІ З УРАХУВАННЯМ ПРОЗОРОСТІ АТМОСФЕРИ
}

\author{
В.П. Гальчак, канд. фіз.-мат. наук, В.М. Боярчук, канд. техн. наук, В.М. Сиротюк, канд. техн. наук, \\ С.В. Сиротюк, канд. техн. наук
}

Львівський національний аграрний університет,

80381, Львівська область, Жовківський район, м. Дубляни, вул. В. Великого, 1

Оиінка ефективності сонячних енергетичних установок з пристроями стеження, але розтатованих у різних кліматичних зонах, часто неможлива внаслідок неповторюваних або важко відтворюваних штучно режимів інсолячії. Тому у розрахунках переважно використовують усереднені середньомісячні значення погодинної зміни інтенсивності прямого потоку сонячної енергії за умови ясного неба, наведені в актинометричних довідниках. Але вони також відображають місиеві особливості інсоляиії, виражені наприклад локальними відхиленнями від симетрії відносно полудня. Відтак енергетичну оцінку пропонується проводити з використанням погодинних значень інтенсивності прямого потоку сонячної енергї̈, розрахованих за однозначно регламентованими параметрами прозорості атмосфери.

Моделювання відповідних залежностей проведено за співвідношенням, рекомендованим Європейським Каталогом сонячноі радіації (ESRA), для випадку моделі ясного неба - показника релеївської складової оптичної товщини ідеальної атмосфери

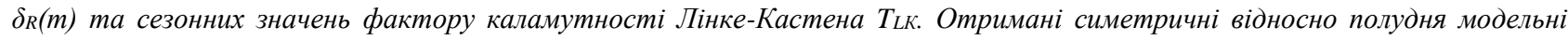
криві співставлені з даними реєстрації на метеостанціях Бориспіль і Ковель, розташованих поблизу широти 50. Помітні відмінності обумовлені місиевими добовими та сезонними особливостями стану реальної атмосфери. У той же час інтегральні показники інсоляції- зареєстровані денні суми прямого потоку сонячної енергії - близькі модельним з врахуванням сезонних змін фактору каламутності: 4-влітку, 3,5 - весняного рівнодення і 3,0 - зимового сонщестояння. Потік сонячноі енергії, розрахований за виразом з відповідними сезону коефіцієнтами, зручний для оцінки поточної потужності $і$ денної продуктивності сонячних енергетичних установок з пристроями стеження у будь якому регіоні. Місиеві особливості інсоляції оцінюються внеском малих відхилень від ідеалізованого потоку. Бібл. 17, табл.3, рис. 5.

Ключові слова: сонячна енергія, модель ясного неба, зенітний кут, оптична товщина атмосфери, фактор каламутності, прямий потік, інтенсивність, енергетична експозиція.

\section{PARAMETERS OF DIRECT SOLAR ENERGY FLUX IN CLEAR SKY TAKEN INTO ACCOUNT OF ATMOSPHERE TRANSPARENCY}

\author{
V. Halchak, candidate of physical and mathematical sciences, V. Boyarchuk, candidate of technical science, \\ V. Syrotyuk, candidate of technical science, S. Syrotyuk, candidate of technical science \\ Lviv National Agrarian University, \\ 80381, Lviv region, Zhovkivsky district, t. Dublyany, V. Velikogo street, 1
}

It is often impossible to make assessment of efficiency of solar power plants with tracking devices, placed in different climatic zones. The reason is that insolation regimes can hardly or never be reproduced artificially. Therefore, calculations mostly apply month average figures of an hourly change of intensity of a direct solar energy flux under conditions of clear sky, which are mentioned in actinometric guides. However, they also describe local features of insolation, such as local deviations from the symmetry with respect to midday. Therefore, energy estimation is proposed to be carried out with the use of hourly values of intensity of a direct solar energy flux, calculated according to the clear regulated parameters of atmospheric transmittance.

Simulation of the corresponding dependencies was carried out according to the correlation, recommended by the European Solar Radiation Atlas (ESRA) for the variant of a clear-sky model, i.e. the indicator of the Rayleign component of the optic thickness of ideal atmosphere $\delta_{R}(m)$ and seasonal character of the values of the Linke-Kasten turbidity factor $T_{L K}$.

The obtained model graphs, which are symmetric with respect to midday, are compared to the data of the registration at the meteorological stations, located in Boryspil and Kovel, close to the latitude of $50^{\circ}$. Significant variations are caused by local daily and seasonal characteristics of the actual atmospheric conditions. However, integral indexes of insolation, particularly the registered daily amounts of direct solar energy flux, are close to the model, with consideration of seasonal changes in the turbidity factor: 4 - in summer, 3,5 - at spring equinox and 3,0 - at winter solstice. The solar flux is measured by the expression with the seasonal corresonding coefficients. The extression is convenient for assessing of the current power and daily productivity of solar power plants with tracking devices in any region. However, local insolation features are estimated by the effect of small deviations from the idealized flux. Ref. 17, tabl. 3, fig. 5.

Keywords: solar energy, clear-sky model, zenith angle, atmospheric optical thickness, turbidity factor, direct flux, intensity, irradiation.

(C) В.П. Гальчак, В.М. Боярчук, В.М. Сиротюк, С.В. Сиротюк, 2019

Відновлювана енергетика. 2019. № 2 


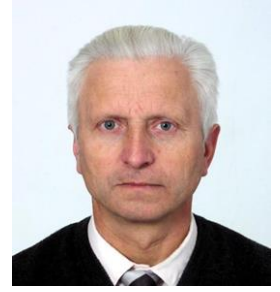

В.П. Гальчак

V. Halchak

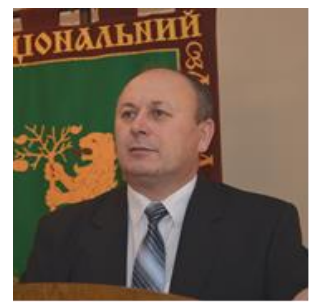

B.М. Боярчук

V. Boyarchuk

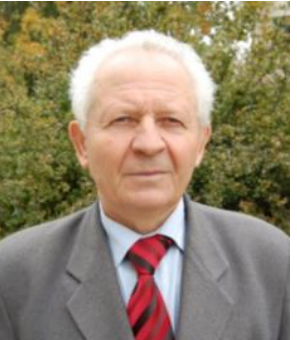

B.M. Сиротюк V. Syrotiuk

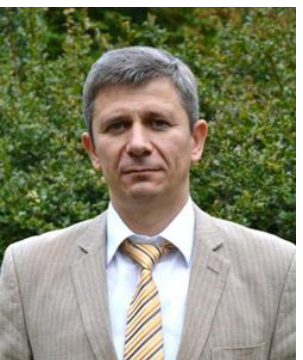

C.B. Сиротюк S. Syrotyuk
Відомості про автора: доцент кафедри енергетики Львівського національного аграрного університету.

Освіта: У 1972 закінчив фізичний факультет Львівського державного університету ім. Івана Франка.

Наукова сфера: відновлювані джерела енергії, сонячна енергетика, вітроенергетика, гібридні системи енергозабезпечення.

Публікації: 180 .

ORCID: 0000-0002-6831-8344

Контакти: тел./факс +38-097-581-43-71

e-mail: halchak@ukr.net

Відомості про автора: перший проректор, професор кафедри енергетики Львівського національного аграрного університету.

Освіта: У 1977 закінчив Львівський сільськогосподарський інститут за спеціальністю "Механізація сільського господарства".

Наукова сфера: відновлювані джерела енергії, сонячна енергетика, вітроенергетика, управління проектами.

Публікації: 300.

ORCID: 0000-0001-8294-8759

Контакти: тел./факс +38-097-581-43-71

e-mail: vim2@ukr.net

Відомості про автора: професор кафедри електротехнічних систем Львівського національного аграрного університету.

Освіта: У 1967 закінчив Львівський сільськогосподарський інститут за спеціальністю "Механізація сільського господарства".

Наукова сфера: відновлювані джерела енергії, сонячна енергетика, вітроенергетика, гібридні системи енергозабезпечення.

Публікації: 200.

ORCID: 0000-0003-4525-9801

Контакти: тел./факс +38-097-900-83-48

e-mail: valsyr@ukr.net

Відомості про автора: доцент, завідувач кафедри енергетики Львівського національного аграрного університету.

Освіта: У 1991 закінчив Львівський державний сільськогосподарський інститут за спеціальністю "Механізація сільського господарства".

Наукова сфера: відновлювані джерела енергіï, сонячна енергетика, вітроенергетика, гібридні системи енергозабезпечення.

Публікації: 150.

ORCID: 0000-0001-9966-6299

Контакти: тел./факс +38-067-939-62-46

e-mail: ssyr@ukr.net
Author information: associate professor of the Department of Energy of Lviv National Agrarian University.

Education: graduated from the Faculty of Physics of Ivan Franko Lviv State University in 1972.

Research area: renewable sources of energy, solar power systems, wind power systems, hybrid power systems.

Publications: 180 .

ORCID: 0000-0002-6831-8344

Contacts: тел./факс +38-097-581-43-71

e-mail: halchak@ukr.net

Author information: first vice-rector, professor of the Department of Energy of the Lviv National Agrarian University.

Education: graduated from the Lviv Agricultural Institute in 1977 with the degree of "Mechanization of Agriculture".

Research area: renewable sources of energy, solar power systems, wind power systems, project management.

Publications: 300 .

ORCID: 0000-0001-8294-8759

Контакти: тел./факс +38-097-581-43-71

e-mail:vim2@ukr.net

Author information: professor of the Department of Electrical Engineering Systems of Lviv National Agrarian University.

Education: graduated from the Lviv Agricultural Institute in 1967 with the degree of "Mechanization of Agriculture".

Research area: renewable sources of energy, solar power systems, wind power systems, hybrid power systems.

Publications: 200.

ORCID: 0000-0003-4525-9801

Контакти: тел./факс +38-097-900-83-48

e-mail: valsyr@ukr.net

Author information: associate professor, head of the Department of Energy of Lviv National Agrarian University.

Education: graduated from the Lviv State Agricultural Institute in 1991 with the degree of "Mechanization of Agriculture".

Research area: renewable sources of energy, solar power systems, wind power systems, hybrid power systems.

Publications: 150.

ORCID: 0000-0001-9966-6299

Контакти: тел./факс +38-067-939-62-46

e-mail: ssyr@ukr.net 


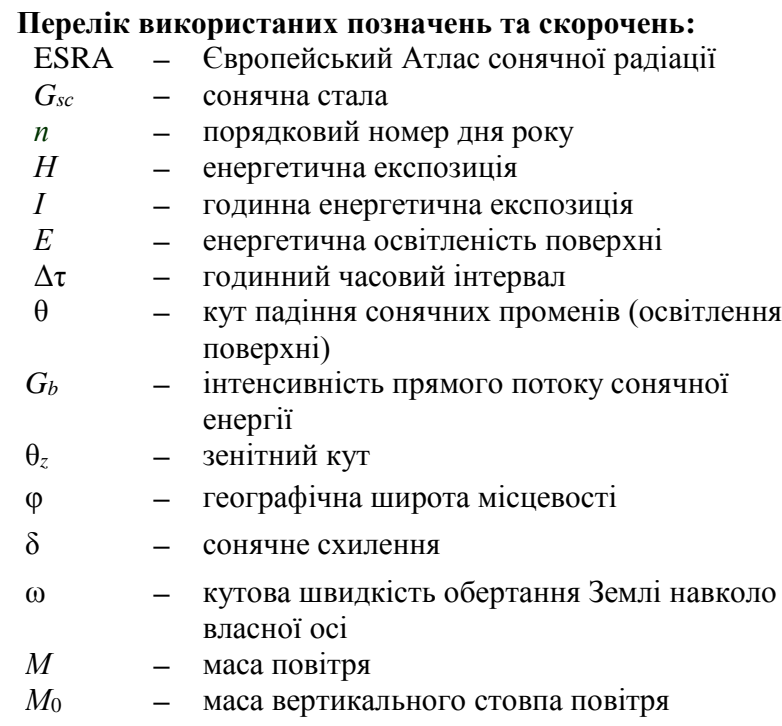

Вступ. Підвищення продуктивності сонячних енергетичних установок за рахунок оптимізації кута освітлення найпростіше досягнути за допомогою пристроїв стеження за Сонцем. Але дотепер відкритим залишається питання кількісної оцінки ефективності проектованих чи реалізованих інсталяцій внаслідок значних відмінностей режимів інсоляції, залежних від години доби пори і року, географічної широти місцевості, погодних та атмосферних явищ тощо. Те ж відноситься і до стаціонарних та дискретно орієнтованих активних і пасивних приймачів сонячної енергії непівденної орієнтації [1].

Ефективність пристроїв стеження досліджували раніше неодноразово у різних кліматичних зонах, на результати яких прийнято посилатися переважно без їх критичної оцінки. Наприклад у монографії [2] ефективність прийнято оцінювати за збільшенням кількості енергії, яка надходить протягом року на поверхню стеження відносно горизонтальної площини. У монографіях [3, 4] порівнюються середньомісячні об'єми енергії, причому у [3] енергія розраховується за припущення освітленням позаатмосферним потоком, а у [4] - усередненим наземним. У монографії [5] наводять погодинні графіки енергетичної освітленості поверхонь стеження стандартизованим потоком (без уточнення назви стандарту) на широті $35^{\circ}$ окремо для кожного сезону року - літнього і зимового сонцестояння та рівнодення.

У монографії [1] освітленість та енергетичну експозицію поверхні оцінюють за параметрами модельованого потоку сонячної енергії, інтенсивність якого розраховують відносно сонячної сталої, але $з$ використанням наближених емпіричних оцінок коефіцієнта прозорості атмосфери. Відповідно запропонована там апроксимаційна формула, обрана за ознаками якісного погоджен-

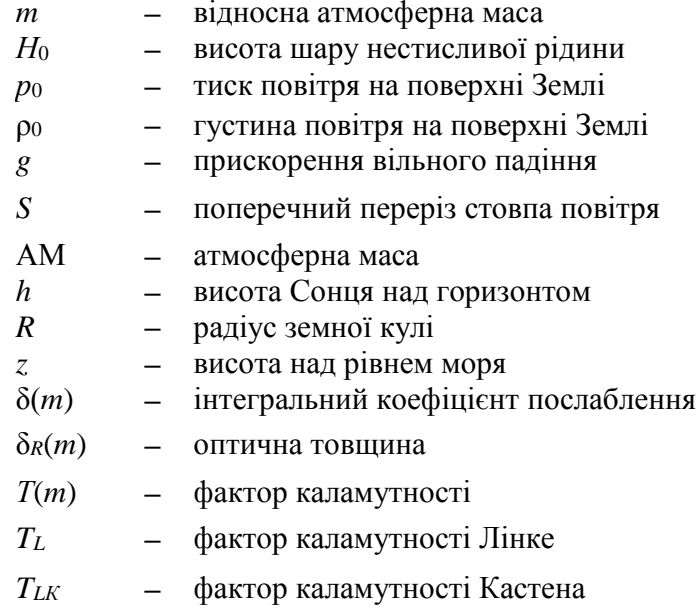

ня 3 статистично усередненими даними реєстрації, насправді відображає тільки особливості інсоляції обмеженого регіону.

Постановка завдання. Порівняння ефективності інсталяцій у різних регіонах і кліматичних зонах необхідно проводити за умови освітлення прямим потоком сонячної енергії, залежним тільки від висоти Сонця над горизонтом. Такий, незалежний від випадкових факторів, ідеалізований потік реалізується тільки за особливо прозорої (ідеальної) атмосфери без водяної пари та аерозолів, яка у природі реалізується надзвичайно рідко. Але її прозорість з високою точністю оцінюється за фундаментальними співвідношеннями і виражається через ефективну оптичну товщину. Відносно неї прийнято оцінювати і прозорість реальної атмосфери і з високою точністю розраховувати інтенсивність потоку сонячної енергії для будь-якої години дня чи висоти Сонця над горизонтом незалежно від географічних координат місцевості. Відомі в актинометрії наближення і співвідношення доцільно проаналізувати 3

метою їх адаптації для методики порівняння ефективності приймачів сонячної енергії довільної орієнтації за незалежними від випадкових факторів критеріями.

Результати дослідження. На вході в атмосферу інтенсивність потоку сонячної енергії протягом року змінюється від максимального 1415 до мінімального $1321 \mathrm{Bт} / \mathrm{M}^{2}$ внаслідок еліптичності земної орбіти. Ї̈ середнє значення, рівне $G_{s c}=1367 \mathrm{BT} / \mathrm{M}^{2}$, називають сонячною сталою (solar constant), а поточні значення $G_{s n}$ для довільного дня року з порядковим номером $n$ і точністю, достатньою для порівняння ефективності енергетичних установок, можна розрахувати за відомою формулою [3]: 


$$
G_{s n}=G_{s c}\left(1+0,033 \cos \frac{360 n}{365}\right) .
$$

Зокрема, станом на день літнього сонцестояння $G_{s n}=1323 \mathrm{BT}^{2} \mathrm{M}^{2}$, весняного рівнодення $1376 \mathrm{BT} / \mathrm{M}^{2}$ і зимового сонцестояння - $1412 \mathrm{BT} / \mathrm{m}^{2}$. Вони значно більші за інтенсивність приземних потоків внаслідок взаємодіючих з атмосферою і їх прийнято характеризувати як миттєвими значеннями так і усередненими протягом дня місяця чи року. Результати систематичних багаторічних наземних вимірювань і розрахунків наводять у вигляді таблиць в актинометричних баз даних, наприклад [6, 7] в Україні.

Ефективність приймачів сонячних енергетичних установок прийнято оцінювати за миттєвою (поточною) потужністю та добовою, середньомісячною чи річною продуктивністю. Отриману приймачем променисту енергію у системі СI оптичних енергетичних величин прийнято називати енергетичною експозицією і позначати латинською літерою $H$ та вимірювати у Вт-год або джоулях. Ця величина $\epsilon$ інтегральною характеристикою потоку сонячної енергії, яку на практиці поділяють на годинну експозицію і позначають літерою $I$ та денну з позначенням $H$ [3]. Представлення потоку енергії у вигляді погодинних сум зручне тим, що іiі значення у Вт.год чисельно рівне інтенсивності потоку сонячної енергії та енергетичній освітленості поверхні $E$ у Вт/м² при нормальному куті освітлення, які вимірюють у таких же одиницях. Відтак виконуються такі важливі для практики обчислень прості співвідношення:

$$
\begin{gathered}
I=E \Delta \tau=G_{b} \cos \theta \Delta \tau, \\
H=\Sigma I,
\end{gathered}
$$

де $\Delta \tau$ - часовий інтервал, рівний 1 годині; $\theta-$ кут падіння сонячних променів (освітлення поверхні); $G_{b}-$ інтенсивність прямого потоку сонячної енергії.

Поточне значення $\cos \theta$ характеризує миттєву (орієнтаційну) ефективність поверхні стеження, тоді як енергетична експозиція - інтегральну (енергетичну) ефективність. Орієнтаційна ефективність рівна поточному значенню $\cos \theta$, яке просто розрахувати за відомими співвідношеннями. Тоді як денний хід інтенсивності сонячних променів визначається як закономірно змінними координатами Сонця на небосхилі, неоднаковим віддаленням приймачів, так і випадковими факторами, залежними від стану атмосфери. Відтак, для порівняння ефективності віддалених приймачів доцільно користуватися унормованими значеннями інтенсивності, залежної тільки від висоти Сонця над горизонтом, яке зручно характери- зувати кутом відхилення від зеніту $\theta_{z}$. Останній легко розрахувати для будь якої місцевості за відомим співвідношенням:

$$
\begin{aligned}
\cos \theta_{z}= & \cos \varphi \cdot \cos \delta \cdot \cos \omega \tau+ \\
& +\sin \varphi \cdot \sin \delta
\end{aligned}
$$

де $\varphi$ - географічна широта місцевості; $\delta$ - сонячне схилення поточного дня року 3 порядковим номером $n$, яке розраховують за формулою

$$
\delta=\delta_{0} \sin \frac{284+n}{365} 360,
$$

де $\omega \tau$ - годинний кут ( $\tau$ - година за сонячним часом і $\omega=15$ град/год - кутова швидкість обертання Землі навколо власної осі).

У координатах сонячного часу за стабільно прозорої атмосфери протягом дня змінні величини симетричні відносно полудня і об'єм розрахунків зменшується вдвічі.

Співвідношення для розрахунку часової залежності нормованої інтенсивності потоку сонячної енергії можна отримати 3 використанням методик, прийнятих в актинометрії. Тому детальніше розглянемо поняття і визначення оптичної маси атмосфери та іiі каламутності, які використовуються для кількісної оцінки послаблення сонячних променів. Усі розрахунки виконують за умови стійкої безхмарної погоди, яку називають наближенням або моделлю ясного неба (clear sky model). У такій атмосфері інтенсивність сонячних променів зменшується внаслідок взаємодії світла 3 компонентами повітря масою $M$ вздовж траєкторії променя в атмосфері. За одиницю порівняння приймається маса вертикального стовпа повітря $M_{0}$, яку можна розрахувати за відомою 3 фізики барометричною формулою. Тоді масу $M$ похилого стовпа повітря зручно оцінювати в одиницях відносної атмосферної маси $m=M / M_{0}$, яку називають оптичною масою. Внаслідок нерівномірної густини повітря і відсутності чіткого визначення критерію верхньої межі атмосфери, значення $m$, оцінюють за наближеними співвідношеннями залежно від області використання.

Найпростіше співвідношення між масою повітря і довжиною похилого стовпа атмосфери отримане для іiі гідравлічної моделі - плоского шару нестисливої рідини висотою $H_{0}$. Відповідно з відомим рівнянням гідростатики

$$
H_{0}=\frac{p_{0}}{\rho_{0} g}=\frac{M_{0}}{\rho_{0} g S},
$$

де $p_{0}$ i $\rho_{0}$ - тиск і густина повітря на поверхні Землі відповідно; $g=9,81 \mathrm{~m} / \mathrm{c}^{2}$ прискорення вільного падіння; $S$ - поперечний переріз стовпа повітря. 
При нормальному атмосферному тиску $p_{0}=101,325$ кПа і температурі $0{ }^{\circ} \mathrm{C}$ густина повітря на поверхні Землі $\rho_{0}=1,293 \mathrm{\kappa} / \mathrm{M}^{3}$, висота $H_{0}=7988$ м. У цій моделі відносна атмосферна маса не залежить від тиску і густини повітря, а при відхилені променя від зеніту на кут $\theta_{z}$ відношення мас рівне відношенню довжин і зводиться до відомої формули для атмосферної маси (АМ):

$$
m=\frac{M}{M_{0}}=\frac{H}{H_{0}}=\frac{1}{\cos \theta_{z}} .
$$

За цим співвідношенням значення $m$ асимптотично прямує до безмежності при наближенні Сонця до горизонту, що не відповідає дійсності. Тому в актинометрії атмосферу моделюють сферичною оболонкою однорідної густини навколо земної кулі. При її похилому просвічуванні значення $m$ розраховують за формулою, доведеною ще Ламбертом [8]:

$$
m=\frac{1}{H_{0}}\left(\sqrt{R^{2} \sin ^{2} h+2 R H_{0}+H_{0}^{2}}-R \sin h\right),
$$

де $h=\left(90^{\circ}-\theta_{z}\right)-$ висота Сонця над горизонтом; $\theta_{z}$ - зенітний кут; $R=6367$ км - радіус земної кулі.

При нормальних умовах на рівні моря $H_{0}=$ $7994 \approx 8000$ м.

За цієї геометричної моделі у моменти сходу чи заходу Сонця $(h=0)$ значення $m$ обмежене і не перевищує максимального 39,9. На нього зазви- чай орієнтуються при модифікації формули (8) для оцінки інтегральної прозорості реальної атмосфери 3 нерівномірним розподілом тиску, температури, вологості, подовження траєкторії променів внаслідок рефракції тощо. У даній публікації використовується модифікована формула Кастена-Йонга [9], рекомендована Європейським Атласом сонячної радіації (The European Solar Radiation Atlas - ESRA) [10]:

$$
m=\frac{\exp \left(-\frac{z}{8334,5}\right)}{\cos \theta_{z}+0,50572 \times\left(96,07995-\theta_{z}\right)^{-1,6354}},
$$

де $z$ - висота над рівнем моря у метрах; 8334,5 коефіцієнт, що відповідає висоті, на якій атмосферний тиск зменшується в $e=2,7193$ раз.

Критична оцінка більшості відомих у літературі співвідношень для розрахунку оптичної маси атмосфери проведена в [11].

Для прикладу у табл. 1 наведено значення оптичної маси атмосфери в інтервалі зенітного кута від нуля до $90^{\circ}$, розрахованих за формулами (7) i (9) для поверхні приймача на рівні моря. При зміні висоти місцевості на 100 м значення атмосферної маси зменшується приблизно на $1,2 \%$, що потрібно враховувати при співставленні модельованих потоків сонячної енергії з природними, виміряними на різних висотах. Відповідні графічні залежності побудовані на рис. 1.

Таблиця 1. Значення атмосферної та оптичної мас за формулами (7) і (9).

Table 1. The values of the atmospheric and optical masses by the formulas (7) and (9).

\begin{tabular}{|c|c|c|c|c|c|c|c|c|c|c|c|c|}
\hline$\theta_{z}$ & 0 & 10 & 20 & 30 & 40 & 50 & 60 & 70 & 80 & 85 & 88 & 90 \\
\hline$A M$ & 1 & 1,015 & 1,064 & 1,155 & 1,305 & 1,556 & 2,000 & 2,924 & 5,759 & 11,474 & 28,65 & $\infty$ \\
\hline $\begin{array}{c}m \text { при } \\
z=0\end{array}$ & 1 & 1,015 & 1,064 & 1,154 & 1,304 & 1,554 & 1,994 & 2,902 & 5,581 & 10,306 & 19,51 & 37,85 \\
\hline
\end{tabular}

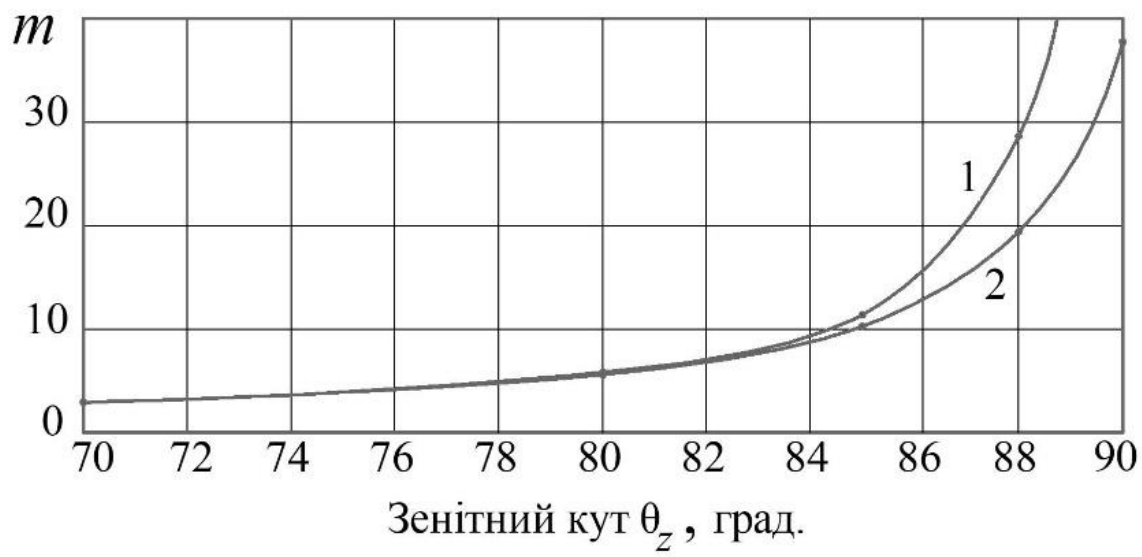

Рис. 1. Оптична маса атмосфери: 1 - за формулою (7); 2 - за формулою (9) .

Fig. 1. Optical mass of the atmosphere: 1 - by the formula (7); 2 - by the formula (9) . 
Прозорість атмосфери в актинометрії кількісно оцінюють через відносну атмосферну масу вздовж ходу променів. За особливостями взаємодії з сонячними променями атмосферу поділяють на ідеальну і реальну. Ідеальна атмосфера складається тільки 3 основних газових молекул компонентів повітря без вуглекислого газу, водяної пари та аерозолів. У ній послаблення сонячних променів відбувається при взаємодії світла з молекулами повітря за двома механізмами: розсіювання Релея та селективного поглинання хвиль певної довжини сонячного спектру молекулами повітря та їх тимчасовими утвореннями (флуктуаціями). Сумарний ефект оцінюють інтегральним коефіцієнтом послаблення $\delta(m)$, залежним від атмосферної маси $m$ на шляху променя. А інтенсивність приземного потоку $G_{b}$ прийнято описувати рівнянням, подібним до формули Ламберта для оптично однорідних середовищ $[12,13]$ :

$$
G_{b}=G_{s n} e^{-\delta(m) \cdot m} .
$$

За аналогією з однорідними прозорими середовищами величину $\delta(m)$ ще називають оптичною товщиною атмосфери. Натомість експоненційний множник

$$
p=e^{-\delta(m)}=\sqrt[m]{\frac{G_{b}}{G_{s n}}}
$$

називають інтегральним коефіцієнтом прозорості атмосфери.

У середніх широтах ідеальній моделі атмосфери найближче відповідає атмосфера високогір'я, а на рівнині - при вторгненні холодного і сухого арктичного повітря. Відтак ії оптичну товщину оцінюють за співвідношенням (10) наземного і позаатмосферного потоків, а результати багатократних вимірювань були узагальнені відомою піргеліометричною формулою Кастена [9]:

$$
\delta_{P}(m)=\frac{1}{9,4+0,9 m} .
$$

Однак пізнішими дослідженнями доведено, що значення, розраховані за цією формулою, помітно занижені, бо грунтуються на спектральних даних з низькою роздільною здатністю, внаслідок чого переоцінено залежність релеївського розсіювання від довжини хвилі $[14,15]$. Відповідно виправлену оптичну товщину додатково позначають індексованим символом $\delta_{R}(m)$, а уточнений вираз для ії розрахунку представляють рівнянням регресії (степеневим поліномом), як, наприклад, у Європейському Атласі сонячної радіації (European Solar Radiation Atlas - ESRA) [10, 16]:

$$
\begin{gathered}
1 / \delta_{R}(m)=6,6296+1,7513 m- \\
-0,1202 m^{2}+0,0065 m^{3}-0,00013 m^{4}
\end{gathered}
$$

при $m<20$ i $h>1,9^{\circ}$,

$$
1 / \delta_{R}(m)=10,4+0,718 m
$$

при $m>20$ і $h<1,9^{\circ}$.

Значення оптичної товщини, отримані за обома формулами (12), (13) і (14) є вихідними параметрами при розрахунку важливих для практики оптичних характеристик реальної атмосфери - видимості каламутності, запиленості тощо. Але в обох випадках вони залежні від оптичної маси атмосфери (рис. 2). Тому нормативними вважають значення, розраховані при $m=2$.

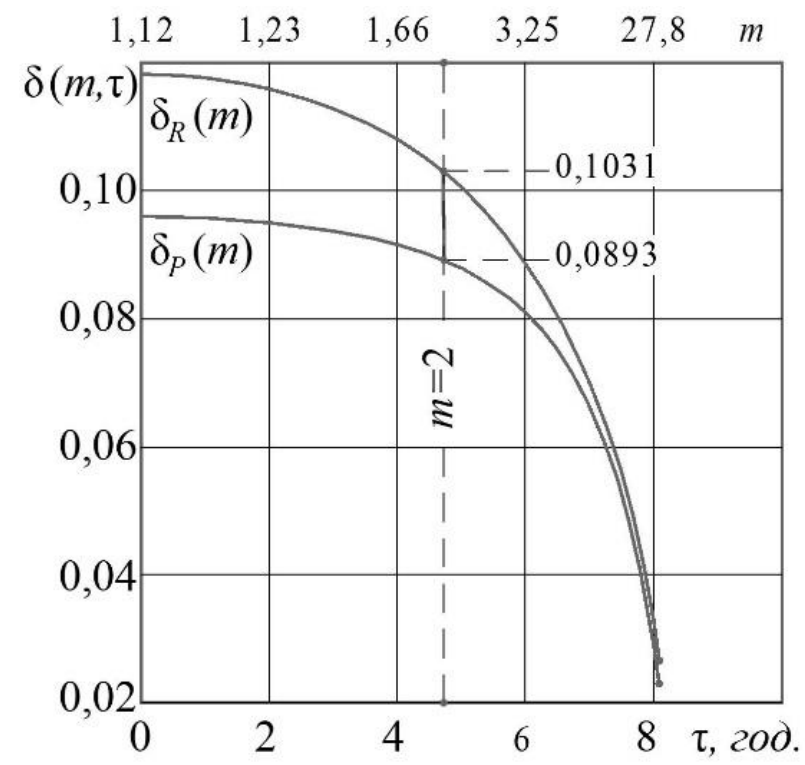

Рис. 2. Співвідношення між оптичними товщинами атмосфери $\delta_{R}(m)$ i $\delta(m)$.

Fig. 2. The ratio between the optical thicknesses of the atmosphere $\delta_{R}(m)$ and $\delta_{P}(m)$.

Вибір точки порівняння пояснюється тим, що у помірних широтах Сонце ніколи не перебуває у зеніті і для зручності обрано найближче цілочисельне значення атмосферної маси. Співвідношення між значеннями обох формул (12), (13) i (14)

$$
\delta_{P}(2) / \delta_{R}(2)=0,0893 / 0,1031=0,8662
$$

надалі використовують як коефіцієнт пропорційності у робочих рівняннях для розрахунку прямого потоку при фіксованій прозорості атмосфери або навпаки.

Реальна атмосфера завжди містить водяну пару, кристалики льоду, краплинки туману та аерозолі. Їх сумарний внесок у послаблення потоку сонячної енергії кількісно оцінюють залежним від оптичної товщини атмосфери фактором каламутності $T(m)$. Це безрозмірна величина характеризує послаблення променів відносно ідеальної атмосфери, яке приймають рівною одиниці. Запропоновані у літературі співвідношення для 
розрахунку фактора каламутності від оптичної маси атмосфери зазвичай додатково індексують за прізвищами авторів: наприклад $T_{L}-$ фактор каламутності Лінке; $T_{L K}$ - Кастена тощо. Зокрема, 3 врахуванням наведених уточнень, інтенсивність приземного потоку сонячної енергії прийнято розраховувати за формулою (10), яка у випадку використання позначення $T_{L K}(A M 2)$, приймає вигляд, наведений у Європейському Атласі сонячної радіації:

$$
G_{b}=G_{s n} \exp \left[-0,8662 \cdot \delta_{R}(m) \cdot T_{L K}(A M 2) \cdot m\right] .
$$

У таблиці 2 наведені результати розрахунків інтенсивності сонячних променій при різних значеннях фактора каламутності. Географічну широту $50^{\circ}$ i висоту приймача на рівнем моря $z=124$ м обрано для зручності порівняння з даними наземних вимірювань метеостанції "Борис-

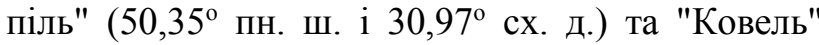
$\left(51,22^{\circ}\right.$ пн. ш. і $24,68^{\circ}$ сх. д., $z=172$ м). Відповідні усереднені параметри потоків сонячної радіації узагальнені у двох метеорологічних довідниках 1966 [6] і 1990 [7] років видання.

Таблиця 2. Інтенсивність прямого потоку $G_{b}$ на широті 50 $\mathrm{i} z=124$ м (метеостанція "Бориспіль").

Table 2. Intensity of direct stream $G_{b}$ at latitude $50^{\circ}$ and $z=124 \mathrm{~m}$ (Boryspil meteorology station).

\begin{tabular}{|c|c|c|c|c|c|c|c|c|c|c|c|}
\hline \multirow{2}{*}{$G_{b},\left(T_{L K}\right)$} & 0 & 1 & 2 & 3 & 4 & 5 & 6 & 7 & 8 & 8,075 & $\Sigma$ \\
\hline & \multicolumn{11}{|c|}{ Літнє сонцестояння $G_{s n}=1323 \mathrm{BT} / \mathrm{M}^{2}$} \\
\hline$\theta_{\mathrm{z}}$ & 26,56 & 29,03 & 36,36 & 43,80 & 53,15 & 62,78 & 72,25 & 81,25 & 89,93 & 90 & - \\
\hline$\overline{\cos \theta_{z}}$ & 0,8945 & 0,8744 & 0,8155 & 0,7218 & 0,5997 & 0,4574 & 0,3048 & 0,1522 & 0,0100 & 0 & - \\
\hline$m$ & 1,1008 & 1,1126 & 1,2072 & 1,3732 & 1,6399 & 2,1463 & 3,2024 & 6,2218 & 27,420 & 37,291 & - \\
\hline$\delta_{R}(m)$ & 0,1188 & 0,1185 & 0,1165 & 0,1133 & 0,1086 & 0,1010 & 0,0892 & 0,0702 & 0,0332 & 0,0269 & - \\
\hline$G_{b}(2)$ & 1056 & 1054 & 1038 & 1012 & 973 & 910 & 809 & 623 & 275 & 233 & 15244 \\
\hline$G_{b}(3)$ & 942 & 939 & 918 & 883 & 833 & 753 & 630 & 425 & 124 & 98 & 12778 \\
\hline$G_{b}(3,5)$ & 890 & 887 & 864 & 825 & 771 & 686 & 556 & 352 & 84 & 63 & 11751 \\
\hline$G_{b}(4)$ & 841 & 838 & 813 & 772 & 714 & 624 & 492 & 291 & 56 & 41 & 10829 \\
\hline \multicolumn{12}{|c|}{ Рівнодення $G_{s n}=1376 \mathrm{BT} / \mathrm{M}^{2}$} \\
\hline$\theta_{\mathrm{z}}$ & 50,00 & 51,62 & 56,17 & 62,97 & 71,25 & 80,42 & 0,00 & - & - & - & - \\
\hline $\cos \theta_{\mathrm{z}}$ & 0,6428 & 0,6209 & 0,5577 & 0,4545 & 0,3214 & 0,1664 & 0,0000 & - & - & - & - \\
\hline $\begin{array}{c}m \\
z=124 \mathrm{M}\end{array}$ & 1,5302 & 1,5939 & 1,7623 & 2,1590 & 3,0367 & 5,6807 & 19,421 & - & - & - & - \\
\hline $\begin{array}{c}\delta_{R}(m) \\
z=124 \mathrm{M}\end{array}$ & 0,1105 & 0,1094 & 0,1066 & 0,1009 & 0,0908 & 0,0788 & 0,0409 & - & - & - & - \\
\hline$G_{b}(2)$ & 1026 & 1017 & 994 & 943 & 853 & 634 & 348 & - & - & - & 11282 \\
\hline$G_{b}(3)$ & 887 & 875 & 844 & 781 & 672 & 430 & 175 & - & - & - & 9153 \\
\hline$G_{b}(3,5)$ & 824 & 811 & 779 & 711 & 666 & 354 & 124 & - & - & - & 8414 \\
\hline$G_{b}(4)$ & 766 & 752 & 718 & 646 & 529 & 292 & 88 & - & - & - & 7494 \\
\hline \multicolumn{12}{|c|}{ Зимове сонцестояння $G_{s n}=1412 \mathrm{BT} / \mathrm{m}^{2}$} \\
\hline$\theta_{\mathrm{z}}$ & 73,45 & 74,64 & 78,12 & 83,56 & 90,00 & - & - & - & - & - & - \\
\hline $\cos \theta_{z}$ & 0,2849 & 0,2648 & 0,2059 & 0,1122 & 0,0000 & - & - & - & - & - & - \\
\hline $\begin{array}{c}m \\
z=124 \mathrm{M}\end{array}$ & 3,4151 & 3,6659 & 4,6615 & 8,0113 & 19,42 & - & - & - & - & - & - \\
\hline $\begin{array}{l}\delta_{R}(m) \\
z=124\end{array}$ & 0,0873 & 0,0852 & 0,0783 & 0,0635 & 0,0409 & - & - & - & - & - & - \\
\hline$G_{b}\left(T_{L}=2\right)$ & 842 & 822 & 750 & 585 & 357 & - & - & - & - & - & 5846 \\
\hline$G_{b}\left(T_{L}=3\right)$ & 651 & 627 & 547 & 376 & 179 & - & - & - & - & - & 4281 \\
\hline $\begin{array}{c}G_{b} \\
\left(T_{L}=3,5\right) \\
\end{array}$ & 569 & 548 & 467 & 302 & 127 & - & - & - & - & - & 3667 \\
\hline
\end{tabular}


На рис. 3 наведені часові залежності інтенсивності прямого потоку, які розраховані за актинометричним співвідношенням (16) для трьох типових періодів року.

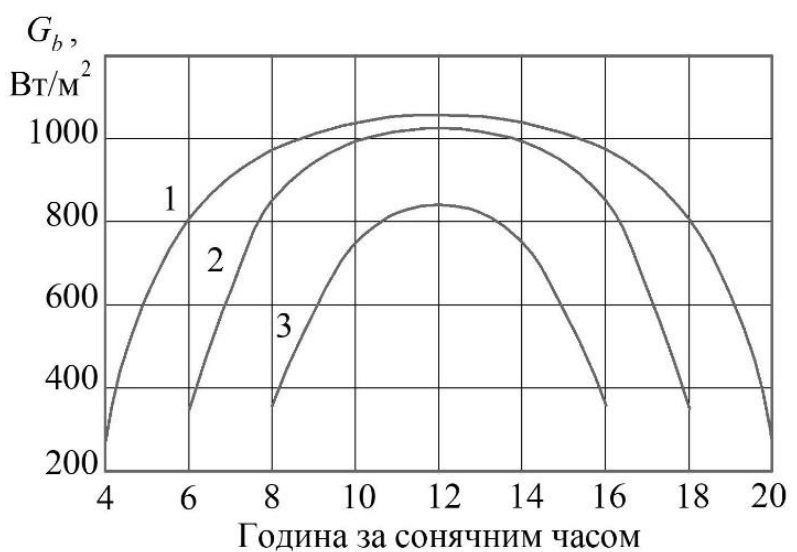

Рис. 3. Сезонні відмінності інтенсивності прямого потоку за дуже прозорого неба $\left(\boldsymbol{T}_{\boldsymbol{L}}=2\right): 1$ - літнього сонцестояння; 2 - весняного рівнодення; 3 - зимового сониестояння.

Fig. 3. Seasonal differences in the intensity of direct flow in a very transparent sky $\left(\boldsymbol{T}_{L}=2\right): 1$ - summer solstice; 2 - vernal equinox; 3 - winter solstice.

На рис. 4 значення усереднених за червень погодинних суми сонячної радіації, зареєстрованих метеостанцією "Ковель", представлено стовпчиковою діаграмою, а чисельно рівні ій значення інтенсивності у Вт/ $\mathrm{M}^{2}$ - неперервною залежністю, відображеною тонкою обвідною лінією. Потовщена крива відповідає розрахованій інтенсивності за рівня каламутності атмосфери $T_{L K}=4$. Натомість на рис. 5 потовщена крива побудована за даними метеостанції "Ковель" у червні, порівнюється 3 двома розрахованими при близьких значеннях фактору $T_{L K}=3,5$ i 4,0.

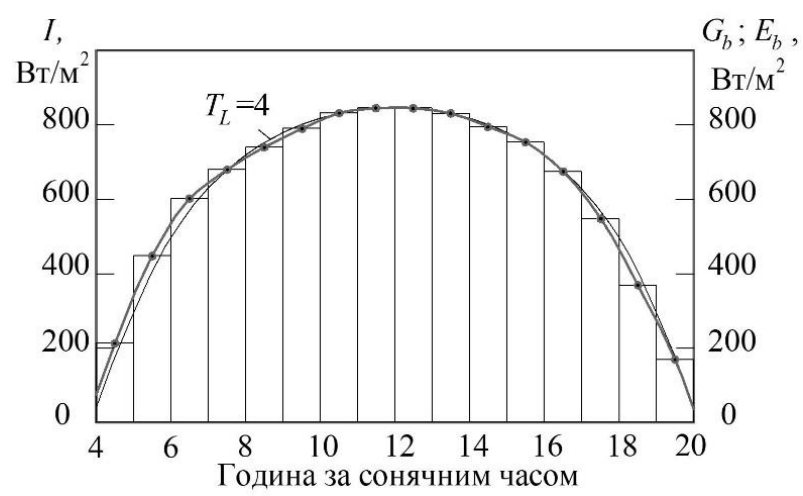

Рис. 4. Погодинні суми енергії I (стовпчики) та інтенсивність потоку $\boldsymbol{G}_{b}$ : природного - обвідна тонка лінія і модельованого при $T_{L K}=4$-лінія нормальної товщини (метеостаниія "Ковель").

Fig. 4. Hourly amounts of energy $I$ (columns) and intensity of flow $\boldsymbol{G}_{\boldsymbol{b}}$ : natural - bypass thin line and modeled with $T_{L K}=4-$ normal thickness line (Kovel meteorological station).
3 графічного порівняння видно, що усереднені дані обох метеостанцій у літній період дуже близькі розрахованим у наближенні ясного неба 3 типовими для літнього сезону рівнями каламутності атмосфери $T_{L K}=3,5 \ldots 4,0$. Незначні відхилення, протилежні на обох рисунках, найімовірніше пояснити випадковими погодозалежними чи місцевими факторами впливу на стан атмосфери та деякою довільністю відповідності актинометричних критеріїв умов реєстрації вимогам моделі ясного неба [17]. Також очевидно, що ці впливи будуть найменшими за мінімальної каламутності атмосфери при $T_{L K}=2$.

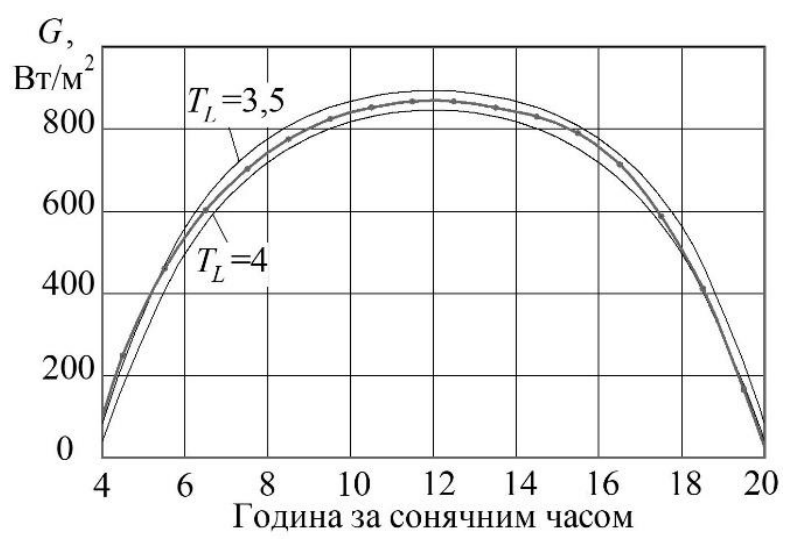

Рис. 5. Кореляція інтенсивності природного потоку на метеостанції "Бориспіль" (потовщена лінія) і модельованого при двох значеннях каламутності атмосфери (тонкі лінії).

Fig. 5. Correlation of the natural flux intensity at the

Boryspil meteorological station (thickened line) and simulated with two values of turbidity of the atmosphere (thin lines).

Інтегральним показником для порівняння ефективності енергетичних установок $з$ пристроями стеження $є$ їх денна продуктивність. Пропорційну продуктивності величину - денну енергетичну експозицію $H$ - легко розрахувати за погодинними табличними значеннями інтенсивності. Враховуючи симетрію розрахованих кривих відносно полудня, стандартний вираз по методу трапецій $з$ погодинним кроком інтегрування зводиться до такого вигляду:

$$
H \approx G_{n} \Delta_{n} \tau+G_{n-1}+2\left(G_{0}+G_{1}+\ldots+G_{n-2}\right) \Delta \tau,
$$

де $\Delta \tau=1$ год; $G_{n}-$ значення в останній колонці таблиці з неповним годинним інтервалом (під час літнього сонцестояння $\Delta_{n} \tau=0,075$ год, а зимового $\left.\Delta_{n} \tau=0,92\right)$.

Результати чисельного інтегрування розрахованих та зареєстрованих значень наведені у таблиці 3 , де жирним шрифтом виділені найближчі довідниковим даним значення. 
Таблиця 3. Денна енергетична експозиція прямого потоку на нормальну до сонячних променів поверхню.

Table 3. Daily energy exposure of direct flow to the normal to the sun's rays surface.

\begin{tabular}{|c|c|c|c|c|}
\hline \multirow{2}{*}{ База даних } & \multicolumn{4}{|c|}{ Денна експозиція $H$, Вт·год/м² } \\
\hline & Літнє сонцестояння & Весняне рівнодення & Зимове сонцестояння & Примітка \\
\hline $\begin{array}{c}\text { Позаатмосферний потік } \\
G_{s n}\end{array}$ & 21366 & 16512 & 11070 & $H=G_{s n} \cdot \tau_{\mathrm{oc}}$ \\
\hline $\begin{array}{c}\text { "Ковель" } \\
\text { Зареєстровано }\end{array}$ & 10161 & 8001 & 4312 & Довідник [7] \\
\hline $\begin{array}{c}\text { "Бориспіль" } \\
\text { Зареєстровано } \\
\text { Розраховано при: } \\
T_{L K}=2 \\
T_{L K}=3 \\
T_{L K}=3,5 \\
T_{L K}=4\end{array}$ & $\begin{array}{l}10572 \\
15244 \\
12778 \\
11751 \\
\mathbf{1 0 8 2 9}\end{array}$ & $\begin{array}{c}8223 \\
11282 \\
9153 \\
\mathbf{8 4 1 4} \\
7494\end{array}$ & $\begin{array}{c}3987 \\
\\
5846 \\
\mathbf{4 2 8 1} \\
3667 \\
-\end{array}$ & Довідник [7] \\
\hline
\end{tabular}

Результати табличного і графічного порівняння відповідають природним сезонним змінам прозорості атмосфери. Різниця визначає величину поправки в енергетичну експозицію та оцінку продуктивності енергетичних установок, при їх натурних випробуваннях у різні періоди року. Це ж відноситься і до одночасної оцінки ефективності установок, але розміщених на різних широтах. У цьому випадку ще потрібно врахувати місцеві особливості інсоляції дифузійною та відбитою складовими загального потоку сонячної радіації. Натомість оцінку приросту продуктивності при різних режимах та алгоритмах стеження і географічних координатах набагато простіше, однозначно і з високою точністю можна розрахувати теоретично, використовуючи ідеалізовані потоки 3 наперед обумовленими параметрами. Процедура узгодження з результатами натурних випробувань зводиться до внесення поправок на к.к.д. установки, місцеві особливості інсоляції та добові календарні відхилення від ідеалізованої часової залежності інтенсивності природного потоку сонячної енергії.

Висновки. Відомі актинометричні співвідношення для розрахунку послаблення сонячних променів земною атмосферою дозволяють, після їх критичного аналізу, розраховувати часові залежності інтенсивності прямого потоку біля поверхні Землі. Їх відповідність результатам наземних вимірювань забезпечується вибором моделі атмосфери 3 врахуванням рівня іiї сезонної каламутності. Розраховані залежності пропонується використовувати для порівняльної оцінки ефективності енергетичних установок, які працюють у різних режимах стеження за Сонцем.

1. Мисак Й.С., Возняк О.Т., Даџько О.С., Шаповал С.П. Сонячна енергетика: теорія та практика. монографія. Львів. вид. Львівської політехніки. 2014. 340 с.
2. Luque A., Hegedus S. Handbook of Photovoltaic Science and Engineering. WILY. 2003. 1179 p.

3. Duffie J. A., Beckman W. A. Solar engineering of thermal processes. 4-d edition. Copyright 2013 by John Wiley \& Sons. Inc.. Hoboken. New Jersey. 910 p.

4. Walker A. Solar Energy. Technologies and the Project Delivery Process for Buildings. Copyright c 2013 by John Wiley \& Sons. Inc. 298 p.

5. Kalogirou S. A. Solar Energy Engineering. Processes and Systems. Second Edition. Amsterdam. Elsevier Inc. 2014. 819 p.

6. Справочник по климату СССР. Вып. 10. Украинская ССР. Ч.1. Солнечная радиация, радиационный баланс и солнечное сияние. Л. Гидрометиздат. 1966. 124 с.

7. Научно-прикладной справочник по климату СССР. Выпуск 10. Украинская ССР. Книга 1. Л. Гидрометиздат. 1990. $595 \mathrm{c}$.

8. Сивков С.И. Методы расчета характеристик солнечной радиации. Л. Гидрометеоиздат. 1968. 232 с.

9. Kasten F., Young T. Revised Optical Air-Mass Tables and Approximation Formula. Applied Optics. 1989. Vol. 28. No.15. Pp. 4735-4738.

10. Scharmer K. Greif J. The European Solar Radiation Atlas. Vol. 1. Paris. Les Presses de l'École des Mines. 2000. 98 p.

11. Matthew J. Reno, Hansen W. Clifford, Stein S. Joshua. Global Horizontal Irradiance Clear Sky Models. Implementation and Analysis. Sandia Report SAND 2012-2389. Unlimited Release Printed March 2012. 67 p.

12. Біловол О.В. Метеорологія. Конспект лекцій. Харків. ХДАДТУ. 2001. 168 с.

13. Хромов С.П., Петросянц М.А. Метеорология и климатология. М. Наука. 2006. 582 с.

14. Ineichen P. Perez $R$. A new air mass independent formulation for the Linke turbidity coefficient. Sol. Energy. 2002. Vol.73. No.3. Pp. 151-157.

15. Gueymard C.A. Critical analysis and performance assessment of clear sky solar irradiance models using theoretical and measured data. Solar Energy.. 1993. Vol. 51. Pp. 121-138.

16. Rigollier $C$., Bauer $O$., Wald L. On the clear sky model of the ESRA - European Solar Radiation Atlas with respect to the Heliosat method. Solar Energy. Elsevier. 2000. No. 68(1). Pp.33-48. URL: https://hal.archives-ouvertes.fr/hal-00361373. Submitted on 13 Feb 2009. 
17. Руководство по актинометрическим наблюдениям для гидрометеорологических станций. Л. Гидрометеоиздат. 1973. 222 c.

\section{REFERENCES}

1. Mysak J.S., Voznyak O.T., Datsko O.S., Shapoval S.P. Sonyachna enerhetyka: teoriya ta praktyka. [Solar Power: Theory and Practice]. Monograph. Lviv. Ukraine. Publishing house Lvivskoyi Politekhniky. 2014. 340 p. [in Ukrainian].

2. Luque A., Hegedus S. Handbook of Photovoltaic Science and Engineering. WILY. 2003. 1179 p. [in English].

3. Duffie J.A., Beckman W.A. Solar engineering of thermal processes. 4-d edition. Copyright by John Wiley \& Sons. Inc.. Hoboken. New Jersey. 2013. 910 p. [in English].

4. Walker A. Solar Energy. Technologies and the Project Delivery Process for Buildings. Copyright by John Wiley \& Sons. Inc.. 2013. 298 p. [in English].

5. Kalogirou S. A. Solar Energy Engineering. Processes and Systems. Second Edition. Amsterdam. Elsevier Inc.. 2014. 819 p. [in English].

6. Spravochnik po klimatu SSSR. [Handbook of climate of the USSR]. Vol. 10. Ukrainian SSR. Part 1 Solar radiation, radiation balance and sunshine Leninhrad. Russia. Gidrometizdat. 1966. 124 p. [in Russian].

7. Nauchno-prikladnoy spravochnik po klimatu SSSR [Applied reference book on the climate of the USSR.]. Issue 10 Ukrainian SSR. Book 1. Leninhrad. Russia. Gidrometizdat. 1990. 595 p. [in Russian].

8. Sivkov S.I. Metody rascheta kharakteristik solnechnoy radiatsii. [Methods for calculating solar radiation characteristics] Leninhrad. Russia. Gidrometizdat. 1968. 232 p. [in Russian].

9. Kasten F., Young T. Revised Optical Air-Mass Tables and Approximation Formula. Applied Optics. 1989. Vol.28. Pp. 4735-4738. [in English].

10. Scharmer K., Greif J. The European Solar Radiation Atlas. Vol. 1. Paris : Les Presses de l'École des Mines. 2000. 98 p. [in English].

11. Matthew J. Reno, Clifford W. Hansen, Joshua S. Stein Global Horizontal Irradiance Clear Sky Models: Implementation and Analysis. Sandia Report SAND 2012-2389. Unlimited Release Printed March. 2012. 67 p. [in English].

12. Bilovol O.V. Meteorolohiya: Konspekt lektsiy. [Meteorology: A summary of lectures]. Kharkiv. Ukraine. KDADTU. 2001. 168 p. [in Ukrainian].

13. Khromov S.P., Petrosyants M.A. Meteorologiya i klimatologiya. [Meteorology and climatology]. Moskow. Russia. Nauka. 2006. 582 p. [in Russian].

14. Ineichen P., Perez R. (2002). A new air mass independent formulation for the Linke turbidity coefficient. Solar Energy. 2006. V. 73. No. 3. Pp. 151-157. [in English].

15. Gueymard C.A. Critical analysis and performance assessment of clear sky solar irradiance models using theoretical and measured data. Solar Energy. 1993. Vol. 51. Pp. 121-138. [in English].

16. Rigollier C., Bauer O., Wald L., Rigollier C. On the clear sky model of the ESRA. European Solar Radiation Atlas with respect to the Heliosat method. Solar Energy. Elsevier. No. 68(1) 2000. Pp. 33-48. Retrived from https://hal.archives-ouvertes.fr/hal00361373 Application date 13.02.2019. [in English].
17. Rukovodstvo po aktinometricheskim nablyudeniyam dlya gidrometeorologicheskikh stantsiy. [Guide to actinometric observations for hydrometeorological stations]. Leninhrad. Russia. Gidrometizdat. 1973. 222 p. [in Russian].

\section{ПАРАМЕТРЫ ПРЯМОГО ПОТОКА СОЛНЕЧНОЙ ЭНЕРГИИ ПРИ ЯСНОМ НЕБЕ С УЧЕТОМ ПРОЗРАЧНОСТИ АТМОСФЕРЫ}

В.П. Гальчак, канд. ф.-м. наук,

В.М. Боярчук, канд. техн. наук,

В.Н. Сиротюк, канд. техн. наук,

С.В. Сиротюк, канд. техн. наук

Львовский национальный аграрный университет, 80381, Львовская область, Жовкивский район, г. Дубляны, ул. В. Великого, 1

Оченка эффективности солнечных энергетических установок с устройствами слежения, но расположенных в разных климатических зонах, часто невозможна вследствие неповторяющихся или трудно воспроизводимых искусственно режсимов инсоляции. Поэтому в расчетах обычно используют усредненные среднемесячные значения почасовой изменения интенсивности прямого потока солнечной энергии при ясного неба, приведенные в актинометричних справочниках. Но они также отражают местные особенности инсоляции, выраженные, например, локальными отклонениями от симметрии относительно полудня. Поэтому энергетическую оценку предлагается проводить с использованием почасовых значений интенсивности прямого потока солнечной энергии, рассчитанных по однозначно регламентированными параметрами прозрачности атмосферы.

Моделирование соответствующих зависимостей проведено по соотношению, рекомендованным Европейским Каталогом солнечной радиаџии (ESRA), для случая модели ясного неба - показателя релеевской составляющей оптической толщины идеальной атмосферы $\delta R(m)$ и сезонных значений фактора мутности Линке-Кастэн ТLК. Полученные симметричны относительно полудня модельные кривые сопоставлены с данными регистрации на метеостанииях Борисполь и Ковель, расположенных вблизи широты $50^{\circ}$. Заметные различия обусловлены местными суточнылми и сезонными особенностями состояния реальной атмосферы. В то же время интегральные показатели инсоляции - зарегистрированные дневные суммы прямого потока солнечной энергии - близкие модельным с учетом сезонных изменений фактора мутности: 4 - летом, 3,5 - весеннего равноденствия и 3,0 - зимнего солнцестояния. Поток солнечной энергии рассчитан по выражению с соответствующими сезона коэффициентами, удобный для оиенки текущей мощңности и дневной производительности солнечных энергетических установок с устройствами слежения в любом регионе. Тогда как местные особенности инсоляиии оцениваются вкладом мальх отклонений от идеализированного потока. Библ. 17, табл.3, рис. 5 .

Ключевые слова: солнечная энергия, модель ясного неба, зенитный угол, оптическая толщина атмосферы, фактор мутности, прямой поток, интенсивность, энергетическая экспозииия. 